UCRL-ID-147941

\title{
Shocked and Stressed, Metals Get Stronger
}

\author{
L. Hackel
}

March 12, 2002

\section{U.S. Department of Energy}

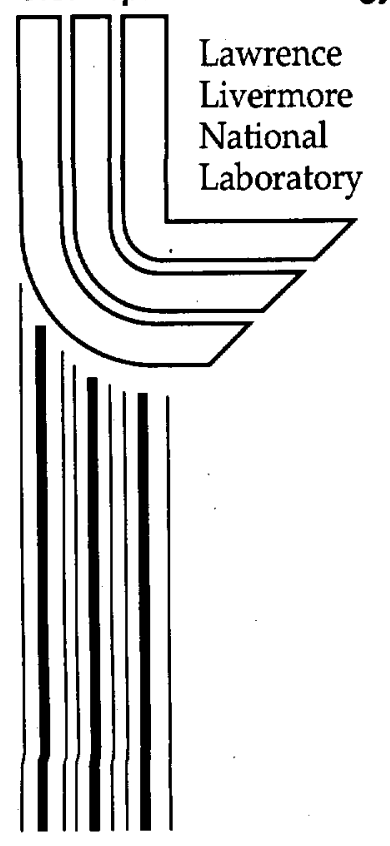




\section{DISCLAIMER}

This document was prepared as an account of work sponsored by an agency of the United States Government. Neither the United States Government nor the University of California nor any of their employees, makes any warranty, express or implied, or assumes any legal liability or responsibility for the accuracy, completeness, or usefulness of any information, apparatus, product, or process disclosed, or represents that its use would not infringe privately owned rights. Reference herein to any specific commercial product, process, or service by trade name, trademark, manufacturer, or otherwise, does not necessarily constitute or imply its endorsement, recommendation, or favoring by the United States Government or the University of California. The views and opinions of authors expressed herein do not necessarily state or reflect those of the United States Government or the University of California, and shall not be used for advertising or product endorsement purposes.

This work was performed under the auspices of the U.S. Department of Energy by the University of California, Lawrence Livermore National Laboratory under Contract No. W-7405-Eng-48.

This report has been reproduced directly from the best available copy.

Available electronically at http://www.doe.gov/bridge

Available for a processing fee to U.S. Department of Energy

and its contractors in paper from

U.S. Department of Energy

Office of Scientific and Technical Information

P.O. Box 62

Oak Ridge, TN 37831-0062

Telephone: (865) 576-8401

Facsimile: (865) 576-5728

E-mail: reports@adonis.osti.gov

Available for the sale to the public from

U.S. Department of Commerce

National Technical Information Service

5285 Port Royal Road

Springfield, VA 22161

Telephone: (800) 553-6847

Facsimile: (703) 605-6900

E-mail: orders@ntis.fedworld.gov

Online ordering: http://www.ntis.gov/ordering.htm

OR

Lawrence Livermore National Laboratory

Technical Information Department's Digital Library

http://www.llnl.gov/tid/Library.html 


\section{Shocked and Stressed, Metals Get Stronger}

P

EOPLE who know their way around metalworking are no doubt familiar with peening - using a ball peen hammer to pound a piece of metal into shape and strengthen it against fatigue failure. For the past 50 years, an industrialized equivalent has been shot peening, in which metal or ceramic beads as large as marbles or as small as salt and pepper grains pneumatically bombard a metal surface Laser peening, a process based on a superior laser technology developed at Lawrence Livermore, replaces the hammer blows and streams of beads with short blasts of laser light. The end result is a piece of metal with significantly improved performance.

Lawrence Livermore and Metal Improvement Company, Inc, won a coveted $R \& D$ 100 Award for their laser-peening process in 1998 (see $S \& T R$, October 1998, pp. 12-13). Since

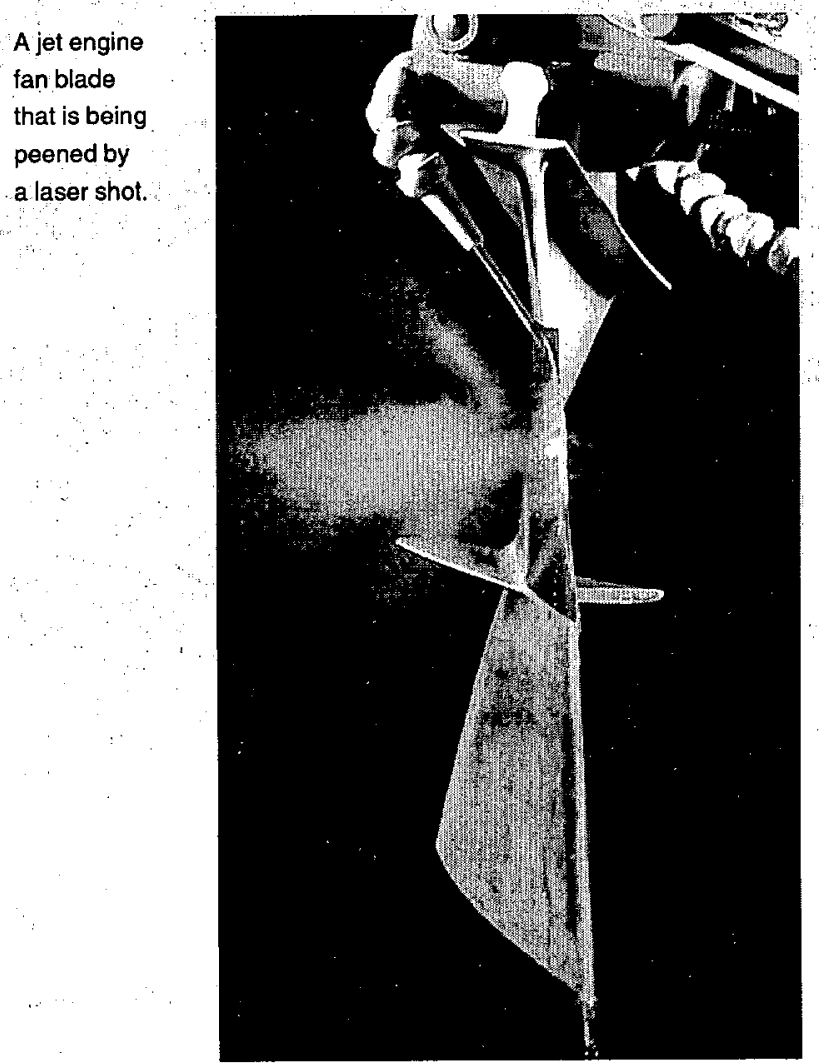

that time, they, ve been developing uses for the technology with a number of industries, including automotive, medical, and aerospace. They ve also developed an offshoot, wh, technique - laser peenmarkingsM - which provides a way to easily and clearly identify parts with a mark that is extremely difficult to counterfeit. Another outgrowth is a new peenforming technology that allows complex contouring of problematic thick metal components such as the thick sections of large aircraft wings. There have also been spinback applications to the Department of Energy's programs for stockpile stewardship, fuel-efficient vehicles, and long-term nuclear waste storage.

\section{Peening with Light}

The concept of laser peening is not new, but took a DOE Cooperative Research and Development Agreement (CRADA) between Livermore and Metal Improvement Company to develop a machine that makes laser peening a cost-effective option. The resultant Lasershot ${ }^{\text {SM }}$ Peening System uses a solid-state, high-energy (50-joule), neodymium-doped glass laser, which pulses at a rate 20 times faster than other available systems and can peen about 1 square meter of metal per hour. With each pulse of the laser, an intense shock wave is created over a roughly 5 -millimeter by 5 -millimeter area and drives in a residual compressive stress about 1 to 2 millimeters deep into metal. In conventional peening, this compressed layer is only about 0.25 millimeter deep. The added depth is key to laser peening's superior ability to keep cracks from propagating and extends the life of parts three to five times over that provided by conventional treatments.

\section{For Fan Blades and Knee Implants}

Shot peening has long been used on automobile springs and transmissions because the treatment increases resistance to cracks, corrosion, and fatigue. Physicist Lloyd Hackel, who heads the Livermore side of the joint development effort, says that the automotive industry is now interested in applying the depth compression afforded by laser peening to automobile frames.

Traditionally, automakers have added mass to the entire frame structure to achieve the required fatigue lifetime and keep high-stress areas in frames from cracking. Now, laser peening can extend fatigue 
lifetime and allow manufacturers to cut back on the weight of the frame. By one company's calculations, laser peening would improve the fatigue lifetime of a 200 -kilogram frame by a factor of two, allowing them to lessen the frame weight by about 20 kilograms. This 20 kilogram weight savings translates into gas savings as well. Laser peening $8 \mathrm{million}$ automobile frames could save about 285 million liters of gasoline per year. "So this technology has two big benefits: it makes the car lighter and cheaper to build, and it results in more fuel efficiency, says Hackel.

Livermore is also working with the Biomechanics Department of the University of California at Los Angeles to use laser peening for knee implants. "The biggest concern in this area is pediatric knee replacement," says Hackel. "A surgeon puts in a small knee joint, the child grows, so the knee is loaded with more stress, which can lead to joint failure. What do you do? Until now, the answer has been to undertake a painful and risky operation every few years to replace the knee with a larger model." In contrast, a laser-peened metal joint would be strong enough to last nearly a decade.

The aerospace industry álso sees major applications for laser peening, particularly in jet engines. "If you look at a modern turbo jet engine such as those used in a Boeing 777 , says Hackel, "you'll see that it's essentially a giant propeller engine, with the fan blades in the front and the compressor blades inside." These blades get hit by a variety of debris including nuts and bolts, seagulls, sand, and rocks, that can cause cracks and failure. Laser peening adds safety while also lowering the life-cycle cost of each fan blade.

Another use of laser peening for aerospace and other industries involves metal shaping. For instance, the leading edge of an airplane wing is basically a big piece of curved metal $A$ erospace and other industries bend metal all the time, but it s difficult to bend very thick pieces and get certain complex shapes. And when you do bend metal, its surface is under tension - think of the metal as being stretched' around that bend. That stretching weakens it and makes it more vulnerable to cracking."

Laser peening just one side of a metal piece will make it naturally bend, which places both peened and unpeened sides under compression and makes the part more resistant to failure. The deep compressive stress and the precise placement of the stress afforded by the laser peening process allows forming of thick, complex shapes never before possible.

\section{Marking by Laser}

Another recently developed application involving industries using or manufacturing metal parts is laser peenimarkingsM, in which a high-resolution mark is imprinted into the metal. This identification mark can take any form, for example, as alpha, numeric characters, a logo, or a data matrix. This development is particularly timely for aerospace industries facing a new marking requirement from the Aerospace Transportation Association, called the ATA 2000 An ATA mark, in a matrix form that can be read by barcode machines, must be set into each part early in the manufacturing process so that the part can be tracked throughout its lifetine.

Normal marking methods - scribing, etching, or stamping remove material or mpart tensile stresses that can leave the part weakened at the marked spot. But laser peenmarking adds a strengthening residual compressive stress. Peenmarks are also of very high resolution, similar to the watermark on currency,
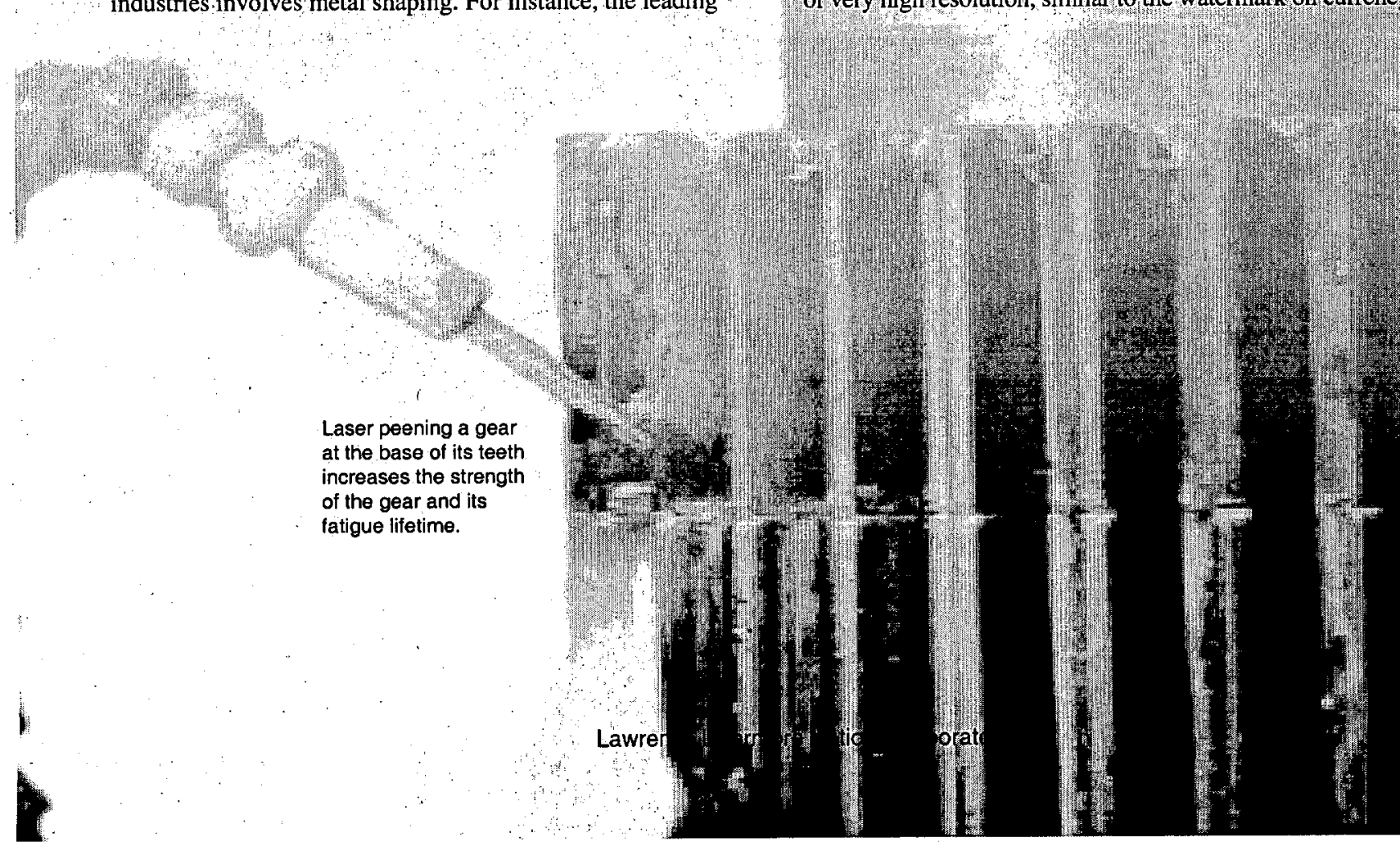


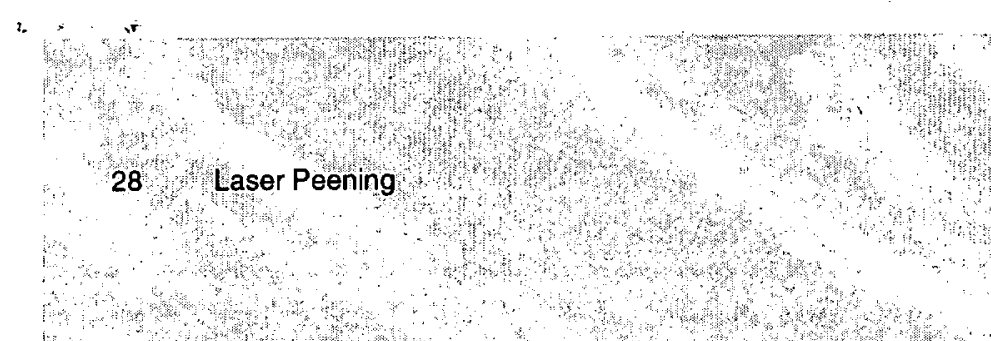

and thereby provide a barrier to counterfeiting. Counterfeit, substandard parts are a major concem, notes Hackel. For example, the U.S. Coast Guard prosecutes approximately 20 cases each year involving the fraudulent use of counterfeit parts. "Laser peenmarking could be an enormous deterrent to criminals and really put a dent in the counterfeit metal parts racket," says Hackel.

Lawrence Livermore and Metal Improvement Company have been working with other organizations, including the National Aeronautics and Space Administration, to determine the efficiency of laser peenmarking. In June 2001, three laser peenmarked parts are tentatively scheduled to ride on the NASA shuttle to the international space station. The parts will be bolted onto the space station to face the slipstream solar wind. After three years, they'll be retrieved and examined to see how well. they held up in the hostile space environment

Laser
peenmarking
prints a complete
high-quality,
machine-readable
matrix mark that
could deter the
counterfeiting of
metal parts. This
data matrix
represents the
number string
"123456."
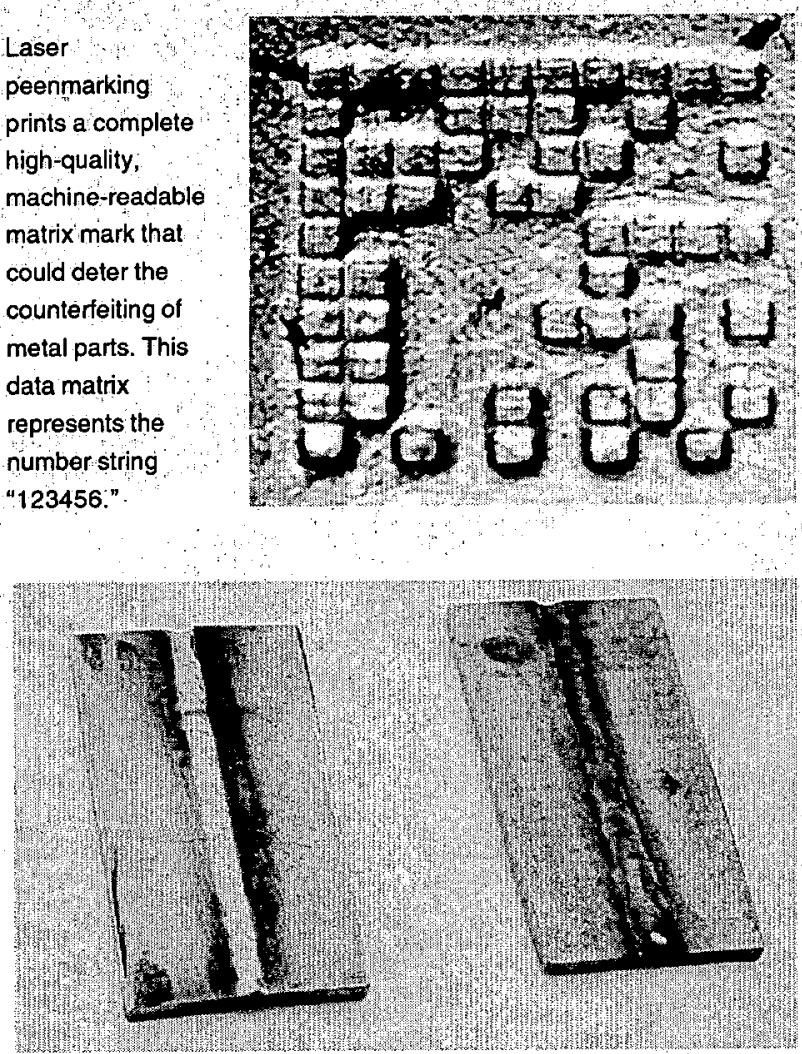

To test the resistance of laser-peened welds to corrosion, the team took two welded pieces of 304 stainless steel and bathed them in a 40-percent solution of magnesium chloride, a highly corrosive salt, at $160^{\circ} \mathrm{C}$. Cracks developed in the unpeened weld within 24 hours, whereas the laserpeened weld showed no observable cracks after a week of exposure.

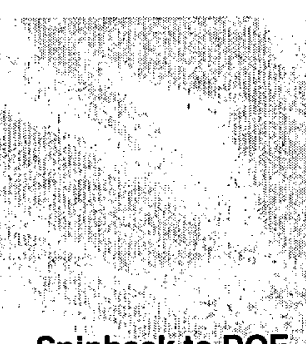

\section{Spinback to DOE}

The laser-peening technology is a spinoff of high-energy lasers developed in the DOE Inertial Confinement Fusion program. Those lasers were brought to high average power with Department of Defense funding. The technology is spinning back home as it becomes clear that peening has relevant applications for DOE's Yucca Mountain Nuclear Waste Disposal and Stockpile Stewardship programs.

For Yucca Mountain, laser peening could be used to prevent stress corrosion cracking in the final closure welds of 6-meter by 1.5 -meter nuclear waste storage canisters. Such canisters must completely contain waste for a minimum of 10,000 years. Analyses show that stress corrosion in some of the canister welds could cause the canisters to fail prematurely. Experiments show that laser peening the welds would keep corrosion and cracking at bay, allowing the canister to remain intact for 10,000 years and more.

In the Stockpile Stewardship Program, one research area seeks to determine the effect of intense strain on various materials. The laser-peening team discovered that it could generate meaningful strain rates and effects through shock waves created by the laser-peening process. We can give stockpile stewardship scientists 10 laser shots a minute, providing them with an enormous amount of data and information," says Hackel. The process, he adds, can give these scientists exquisite control over test parameters, including the intensity, duration, and profile of the desired shock wave.

As for DOE's efforts in promoting fuel efficiency in vehicles, Hackel says, "I see peening as another spinback for the DOE- particularly the Office of Transportation Technology -in terms of reducing the weight of vehicles. DoD would also benefit, from getting better fuel efficiency in the field and also for airlift capability."

\section{Far-Reaching Technology}

Going from ball-peen hammers to laser light takes a big jump in technology. The applications of laser peening - some known years ago, others newly discovered -are just as far-reaching. "What we've come to," says Hackel; "is an active CRADA. that's working to field the technology for specific industries and spinning it back with important benefits to Laboratory and DOE work.",

-Ann Parker

Key Words: Laser peening, Stockpile Stewardship Program, Yucca Mountain Nuclear Waste Disposal Program.

For further information contact Lloyd Hackel (925) 422-9009 (hackel1@IInl.gov) 